УДК 338.439:631.147

Жибак М.М., д.е.н., професор

Христенко Г.М., к.е.н., доцент

Відокремлений підрозділ Національного університету біоресурсів і природокористування України «Бережанський агротехнічний інститут»

\title{
СВІТОВИЙ РИНОК ОРГАНІЧНОЇ ПРОДУКЦЇ̈: СУЧАСНИЙ СТАН ТА ПЕРСПЕКТИВИ РОЗВИТКУ
}

У статті проаналізовано сучасний стан розвитку органічного виробництва в світі. Виявлено основні економічні, екологічні та соціальні переваги органічного виробництва. Розглянуто світовий досвід виробництва та споживання органічної продукції. Визначено передумови успішного розвитку органічного виробництва у країнах-членах ЄС. Обгрунтовано перспективи розвитку світового ринку органічної продукції.

Ключові слова: світовий ринок органічної продукції, розвиток, органічне агровиробництво, органічна продукція, попит, споживання.

Zhybak M., Khrystenko H.

\section{WORLD MARKET OF ORGANIC PRODUCTS: CURRENT STATE AND PROSPECTS OF DEVELOPMENT}

The article analyzes the current state of development of organic production in the world. The basic economic, ecological and social advantages of organic production are revealed. The world experience of production and consumption of organic products is considered. The preconditions for the successful development of organic production in the EU member states are determined. The prospects of development of the world market of organic products are substantiated.

Key words: world market of organic products, development, organic farming, organic produce, demand, consumption.

Жибак М.М., Христенко Г.М.

\section{МИРОВОЙ РЫНОК ОРГАНИЧЕСКОЙ ПРОДУКЦИИ: СОВРЕМЕННОЕ СОСТОЯНИЕ И ПЕРСПЕКТИВЫ РАЗВИТИЯ}

В статье проанализировано современное состояние развития органического производства в мире. Выявлены основные экономические, экологические и социальные преимущества органического производства. Рассмотрены мировой опыт производства и потребления органической продукции. Определены предпосылки успешного развития органического производства в странах-членах ЕС. Обоснованы перспективы развития мирового рынка органической продукции.

Ключевые слова: мировой рынок органической продукции, развитие, органическое агропроизводство, органическая продукция, спрос, потребление.

Постановка проблеми у загальному вигляді і ї̈ зв'язок з важливими науковими та практичними завданнями. Загострення екологічних проблем в світі, спричинених інтенсифікацією аграрного виробництва, вимагають застосування альтернативних методів господарювання, спрямованих на забезпечення збалансованої динамічної рівноваги соціально-еколого-економічних складових агропродовольчої системи. Найпоширенішим серед альтернативних способів землеробства $\epsilon$ органічне виробництво, яке сприяє зниженню негативної дії антропогенного впливу на довкілля, гармонійному розвитку екосистеми, забезпеченню населення якісними продуктами харчування та вирішенню проблеми продовольчої безпеки. 
У європейських країнах органічне виробництво, як важливий пріоритет Спільної аграрної політики (САП) Свропейського Союзу, є сформованою галуззю, яка визначає їх роль і місце у міжнародному територіальному поділі праці.

Аналіз останніх досліджень, у яких започатковано вирішення проблеми. Дослідженню теоретичних і практичних основ формування ринку органічної продукції присвячено праці зарубіжних та вітчизняних вчених, зокрема Н. Берлач, Н. Бородачевої, О. Варченко, В. Вовк, Л. Дейнеко, Т. Дудар, Т. Зайчук, І. Іртищевої, О. Корчинської, О. Рудницької, Х. Ніберг, Ф. Офферман, С. Падель, О. Ралко, О. Томашевської, С. Фостер, Т. Чайки та ін.

Незважаючи на значну кількість вітчизняних та зарубіжних праць, питання наукового обгрунтування місця органічного сільського господарства в сучасній агроекономічній системі, умов формування ринку органічної продукції залишаються недостатньо дослідженими та потребують подальшого опрацювання.

Цілі статті. Метою статті $\epsilon$ аналіз світового ринку органічної продукції та визначення пріоритетних напрямів його розвитку.

Виклад основного матеріалу дослідження 3 повним обгрунтуванням отриманих наукових результатів.

Зростаючі вимоги до якості продукції та безпечності довкілля стають головними рушійними силами виробництва в розвинених країнах світу. Ступінь продовольчої та екологічної безпеки значно обумовлений альтернативними технологіями в галузі сільського господарства, серед яких найбільший розвиток отримало органічне виробництво.

За визначенням Міжнародної федерації розвитку органічного землеробства (IFOAM) «органічне сільське господарство - це виробнича система, яка підтримує здоров'я грунтів, екосистем і людей» [3].

Світова багаторічна практика демонструє економічні, екологічні та соціальні переваги органічного виробництва, найважливішими серед яких є:

-підвищення незалежності виробника від зовнішніх джерел фінансування;

-ресурсозбереження та зменшення енергоємності сільськогосподарського виробництва;

-підвищення рівня продовольчої безпеки;

- мінімізація впливу агровиробничих процесів на довкілля;

-збереження та покращення стану природного середовища в процесі виробництва;

-сприяння збереженню та відновленню біорізноманіття в агроландшафтах;

-забезпечення екологічної рівноваги довкілля;

-забезпеченню населення якісними екологічно чистими продуктами харчування.

Ринок органічної продукції впродовж останніх десятиліть $€$ найдинамічнішим ринком у світі і має високий потенціал розвитку. Зростання світового ринку органічної продукції відбувається головним чином завдяки збільшенню попиту в найбільш розвинених країнах світу, який забезпечується переважно пропозицією країн, що розвиваються.

У світі органічним виробництвом у 2016 р. займалися в 178 країнах близько 2,7 млн виробників. Починаючи з 1999 р. чисельність виробників органічної продукції зросла майже у 14 разів. Аналіз розподілу виробників органічної продукції за регіонами свідчить, що більшість 3 них представляють країни, що розвиваються. Так, в Азії зосереджено 40\% світових виробників органічної продукції, Африці - 27\%, Латинській Америці - 17\%, Свропі - 14\%, Північній Америці - 1\%, Австралії та Океанії-1\%. Серед лідерів за кількістю виробників органічної продукції: Індія - (835,2 тис. од.), Уганда (210,3 тис. од.) та Мексика (210 тис. од.) [5]. 
Загальна площа земель, зайнятих під органічним землеробством, у світі на кінець 2016 р. становила 57,8 млн га (рис. 1). Стрімке зростання (до 10\% на рік) площ сільськогосподарських угідь, зайнятих під органічним виробництвом, розпочалось 3 1990 р. і тривало до 2002 р. Найбільше зростання площ органічних земель в історії спостерігаємо у 2016 р. - на 7,5 млн га, або 15\% у порівнянні з 2015 р.

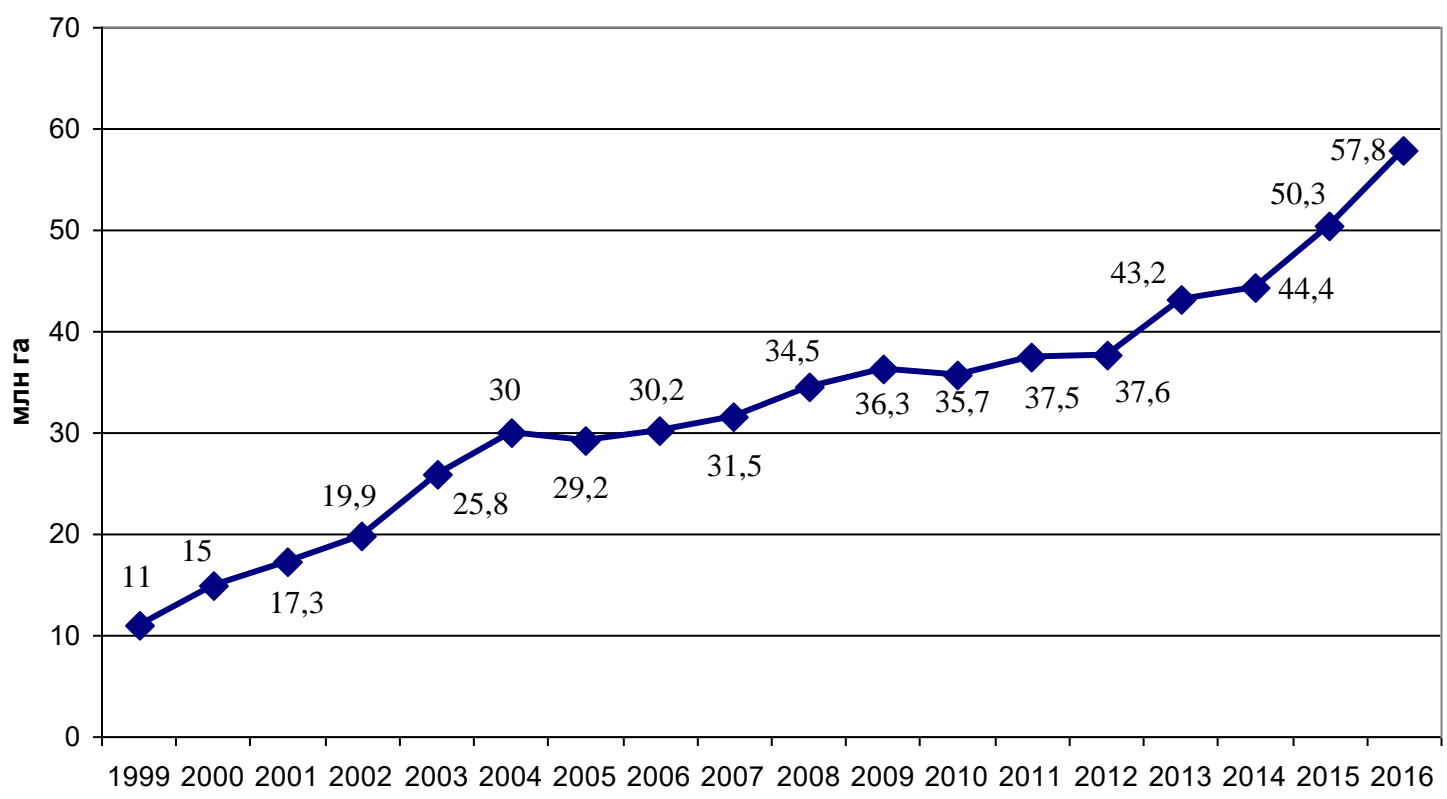

Рис. 1. Динаміка площ органічних сільськогосподарських угідь у світі, млн га.

Побудовано за даними [7].

Майже половина всіх органічних сільськогосподарських земель світу зосереджена в Океанії (27,3 млн га, або 47\%), в Свропі - 13,5 млн га (23\%), Латинській Америці - 7,1 млн га (12\%), Азії - 4,9 млн га (9\%), Північній Америці - 3,1 млн га (6\%), Африці - 1,8 млн га (3\%).

Світовими лідерами за площею органічних сільськогосподарських земель $є$ Австралія (27,2 млн га, майже третина всіх сертифікованих органічних земель), Аргентина (3,0 млн га), Китай (2,3 млн га), США (2,0 млн га), Іспанія (2,0 млн га), Італія (1,8 млн га), Уругвай (1,7 млн га), Франція (1,5 млн га), Індія (1,5 млн га) та Німеччина (1,3 млн га) [5].

Частка сертифікованих органічних земель у загальній площі сільськогосподарських угідь за даними 2016 р. коливається у різних країнах від нуля до 37,7\% (Ліхтенштейн), що $\epsilon$ найвищим показником у світі. Слід зазначити, що в 15 країнах світу частка органічних земель складає 10 або й більше відсотків.

Ріст органічних сільгоспугідь продовжує відставати від росту попиту на органічну продукцію. Однак в останні роки площі, відведені під органічне виробництво зростають більш швидкими темпами, ніж у попередні роки.

У Європейському Союзі площа угідь, зайнятих під органічним виробництвом, становила у 2016 р. 12,1 млн га, що на 8,2\%, або майже на 1 млн га більше порівняно із 2015 р. Частка органічних земель від загальної площі сільськогосподарських угідь в ЄС становила $6,7 \%$. При цьому в розрізі країн-членів $\mathrm{CC}$ цей показник значно різниться. Найбільші площі органічних угідь мали Іспанія (2 млн га), Італія (1,8 млн га) та Франція (1,5 млн га). Країнами 3 великою часткою земель, сертифікованих як органічні, традиційно є Австрія (21,9\%), Естонія (18,9\%), Швеція (18\%) [2].

В Європейському Союзі зареєстровано 295,1 тис. виробників органічної продукції, що на 7,8\% більше порівняно із 2015 р. Країни-лідери за кількістю виробників органічної продукції: Італія (64,2 тис. од.), Іспанія (36,2 тис. од.) та Франція (32,3 тис. од.) 
Світовий ринок органічної продукції зростає високими темпами, щороку на 10$15 \%$, і у 2016 р. сягнув понад 80 млрд євро. Споживчий попит на органічну продукцію зосереджено, в основному, в економічно розвинутих країнах світу.

Світовим лідером за обсягом збуту органічної продукції є США з товарообігом 38,9 млрд євро (46\% світової реалізації органічної продукції). Друге місце посідає Німеччина 3 обсягом реалізації 9,5 млрд євро (11\%), третє - Франція (6,7 млрд євро, або 8\%). Слід зазначити, що товарообіг більшості основних ринків у 2016 р. продовжував зростати більше, ніж на 10\%.

За принципом єдиного (спільного) ринку (з єдиною грошовою одиницею) найбільшим є також сегмент США (46\%). Ринок країн Європейського Союзу становить $36 \%$. Новим сегментом став ринок Китаю (7\% роздрібної торгівлі світу), практично незмінною залишається частка ринків Канади (3\%) та Швейцарії (3\%). На ринки інших країн і регіонів світу припадає лише 5\% торгівлі органічною продукцією (рис. 2).
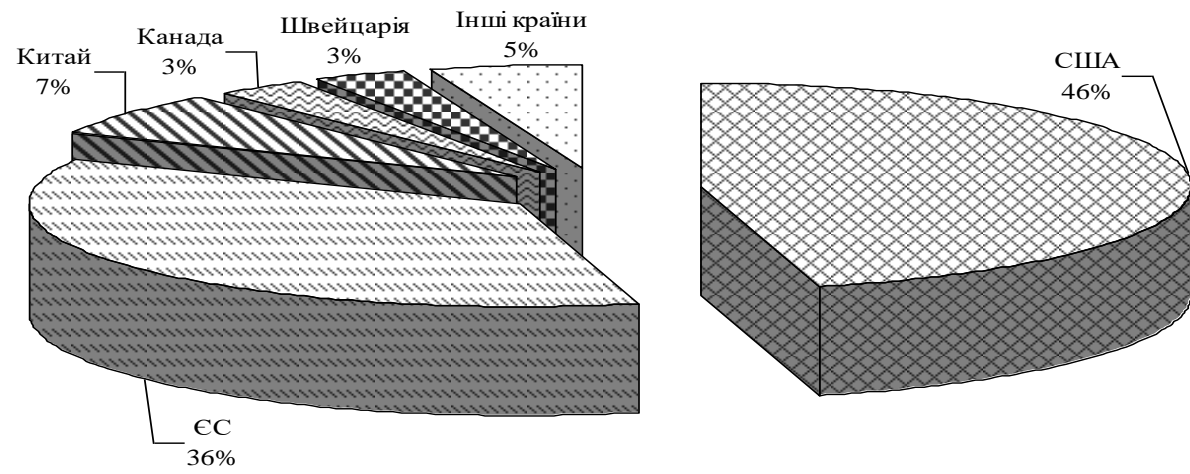

Рис. 2. Розподіл обсягів роздрібного товарообороту органічною продукцією за принципом єдиного (спільного) ринку, 2016 р., \%.

Джерело: побудовано за даними [2].

Дослідження показали, що країни з найбільшими ринками органічної продукції належать до групи найбільш розвинутих країн світу. Так, лідером у світі є США, забезпечуючи $43 \%$ обсягів реалізації органічної продукції.

За місткістю ринків органічної продукції у світі виділяються 10 країн (рис. 3). В цілому за показником місткості ринку характерні значні відмінності між країнами. Смність ринку Франції становить понад 6,7 млрд євро, Китаю - 5,9 млрд євро. Найчисленнішою є група країн з обсягом реалізації органічної продукції в межах 2,0-3,0 млрд євро, яка включає Швейцарію, Італію, Великобританію, Канаду. В Іспанії та Швеції ємність ринку сягає до 2,0 млрд євро.

Європейський ринок органічної продукції за 2016 р. зріс на 12\% і досяг майже $€ 33,5$ млрд євро (зокрема, в Євросоюзі - до €30,7 млрд євро). Європейський Союз є другим найбільшим єдиним ринком органічної продукції в світі після США. Європейський ринок продемонстрував рекордне зростання на $11 \%$ (СС - на $12 \%)$. Це вдруге, $з$ часів фінансової кризи, роздрібний товарообіг перевищив 10\%. Серед ключових ринків найбільше зростання спостерігалося у Франції (22\%) [4; 5]. Протягом останнього десятиріччя товарообіг ринків Свропи та ЄС зріс майже вдвічі.

Рушійною силою розвитку світового ринку органічної продукції $\epsilon$ стабільно зростаючий попит в розвинених країнах при одночасному формуванні пропозиції в країнах, що розвиваються. Основна частка обсягів продажу органічної продукції припадає на ринки Північної Америки і Європи. Ці два регіони, володіючи приблизно третиною органічних сільськогосподарських земель світу, споживають близько 90\% органічної харчової продукції, виробленої переважно в країнах Азії, Латинської Америки і Африки. 


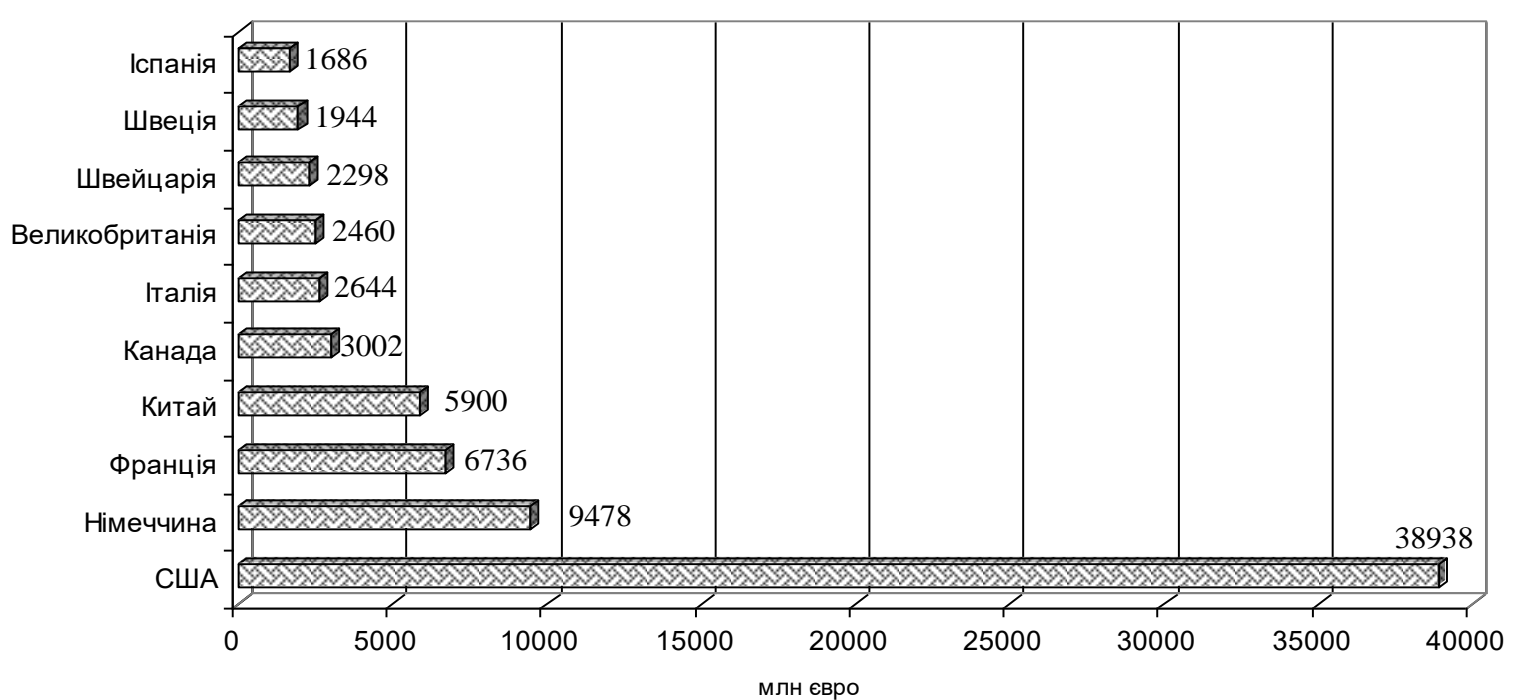

Рис. 3. Країни з найбільшими ринками органічної продукції, 2016 p.

Побудовано за даними [2].

У світовому масштабі європейські країни мають найбільшу частку продажів органічних продуктів у загальному обсязі ринку продуктів харчування. Лідерство у світі належить Данії $(9,7 \%)$. Досить висока частка органічного ринку в Люксембурзі $(8,6 \%)$ та Швейцарії $(8,4 \%)$.

Головними споживачами органічної продукції є розвинуті країни, в яких високий рівень доходів населення забезпечують високий платоспроможний попит на органічну продукцію. Країни з найвищим рівнем споживанням органічної продукції продовжують демонструвати позитивну динаміку.

США $є$ водночас одним з найбільших експортерів органічної продукції у світі.

євро/рік

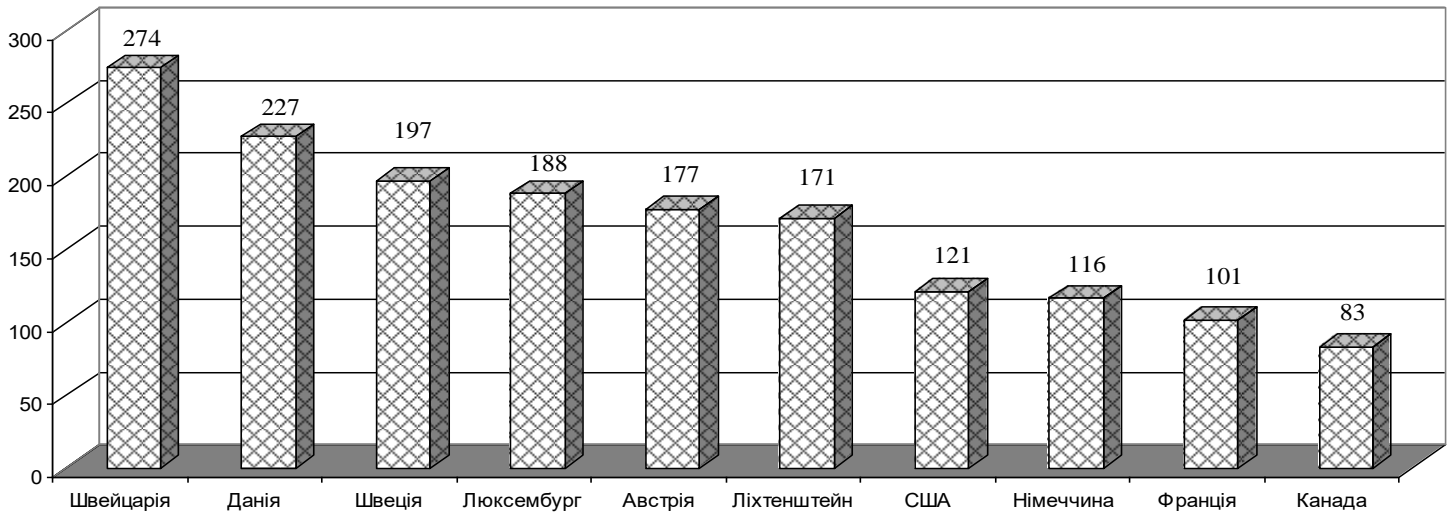

Рис. 4. Споживання органічної продукції в розрахунку на душу населення у країнах світу, євро/рік, 2016 р.

Джерело: побудовано за даними [2].

Встановлено, що мешканець планети у середньому на органічну продукцію витрачає 11 євро на рік. При цьому країнами світу з найвищими питомими показниками споживання органічної продукції з розрахунку на душу населення є Швейцарія (274 євро), Данія (227 євро), Швеція (197 євро), Люксембург (188 євро) (рис. 4). Встановлено, 
що пересічний європеєць на органічні продукти витрачає 40,8 євро на рік, а мешканець СС - 60,5 євро.

За оцінками Продовольчої та сільськогосподарської організації ООН (ФАО) у перспективі попит на органічну продукцію у світі зростатиме в міру розвитку економіки країн, підвищення рівня освіти та доходів населення.

Дослідження показали, що передумовами успішного розвитку органічного виробництва у країнах-членах ЄС є: міцна інституційно-правова база, фінансова допомога виробникам органічної продукції, сприяння популяризації органічного виробництва, підтримка розвитку науки i дорадництва, довіра до маркування екологічного сільського господарства, зростання попиту на екологічну продукцію за кордоном та всередині країн, адміністративна підтримка через державні замовлення та держзакупівлі, надання пільгових кредитів агровиробникам тощо.

Висновки. Ринок органічної продукції $\epsilon$ перспективним сегментом агропродовольчого ринку розвинутих країн світу. Нині значно зріс інтерес споживачів до якісної екологічно безпечної продукції. Органічне агровиробництво, як перспективна для більшості країн світу галузь, дозволяє реалізувати концепцію сталого розвитку агросфери за рахунок соціально-економічної й природно-ресурсної збалансованості.

\section{Список використаних джерел:}

1.Артиш В.І. Виробництво та реалізація органічної продукції в світі. Економіка АПК. 2017. № 3. С. 82-86.

2.Розвиток органічного ринку - Україна та світ. Інформаційний бюлетень. Березень 2018 p. URL: www.organicworld.net/yearbook/yearbook-2018.html

3.IFOAM Basic Standarts (approved by the IFOA General Assembly, Victoria, Canada, and august 2002). URL: http://www.ifoam.org

4.FiBL \& IFOAM - Organics International (2016); The World of Organic Agriculture 2016. Frick and Boon.

5.FiBL \& IFOAM. Organics International (2017). Frick and Bonn, 2017. URL: https://shop.fibl.org/chen/mwdownloads/download/link /id

6.http://organicukraine.org.ua/congress/

7.https://superagronom.com/news/3482-predstavleno-kartu-organichnih-zemel-ukrayini

UDC339.142:339.167

Cimpoies Liliana, $\mathrm{Ph}$. D., associate professor

Academy of Economic Studies, Moldova

\section{AGRI-FOOD TRADE AND THE E.U. MARKET: OPPORTUNITIES AND CHALLENGES FOR MOLDOVA}

The aim of this paper is to assess the development on Moldova's agri-food trade flows on the E.U. market. Thus the main changes and tendencies in the agri-food trade structure and distribution markets is analyzed. The research is based on the analysis of secondary data, provided by National Bureau of Statistics. The examined time series belong to 2012-2017. Trade liberalization has as a positive outcome an increase in the volume of agri-food exports of Moldova, particularly in terms of specialization and concentration of production and diversification of the geographical distribution. Another positive result is the decrease in the dependence on traditional markets. This fact imposed the increase in both quality and variety of exported articles. Due to the DCFTA there is an increase in trade flows with E.U. The agri-food market is important for the stabilization of the national economy, because of its valuable contribution to GDP. Thus is important that the government supports the modernization of the agrifood sector and stimulates to attract investments which will run its further orientation.

Key words: agri-food products, DCFTA, trade.

\section{АГРОПРОМИСЛОВА ТОРГОВЛЯ И Е.С. РЫНОК: ВОЗМОЖНОСТИ И ВЫЗОВЫ МОЛДОВЫ}

Целью данного исследования является оценка развития потоков сельскохозяйственной и продовольственной торговли Молдовы на рынок ЕС. Таким образом, анализируются основные 